\title{
The Didactic of Sustainable Development Terms in Science Education
}

\author{
Fatih SEKER \\ Kastamonu University, Faculty of Education \\ sekerfatih@gmail.com
}

Bahattin AYDINLI

Kastamonu University, Faculty of Education

baydinli@gmail.com

\begin{abstract}
Nowadays, sustainable development is frequently recited in science education also. There are various definitions which are distilled and extracted from educational research. However, the definitions are ambiguous and somehow contrary to each other. Generally, sustainable development was settled on the triangle of ecology, economy and society. Additionally, it has participation with biodiversity, energy resources, recycling and clean environment. Beside these, socioeconomic issues are one of the functional part of it. Here, it is handled with didactic perspective for incorporation to educational program. And it is concluded that sustainable development has participatory democratic structure. And it opens a new road in decision making.
\end{abstract}

Keywords: Sustainability, ecology, energy, society, development, educational program.

\section{Introduction}

Various environmental problems have arisen due to industrial development, waste amount, rapid population increase, technological advances, urbanization increasing with migration from rural area to urbans, and skyscrapers. Competition between the countries in terms of technologic information and economy has led to the development of trade and resulted in crossing the national borders. This has deteriorated the resource and needs analysis, and efforts to reach social welfare have begun to pose a threat for the future of people (Sewilam, McCormack, Mader \& Raouf, 2015). While fulfilling the needs in terms of individuals, communities and countries, pressure on the nature has increased and ecological carrying capacity of the world has been exceeded. People still assume that natural and available resources are limitless (Ruff \& Olson, 2009). Countries that developed rapidly in 1900 and afterwards had used the natural resources for economic development and they had provided the economic development. Natural resources were used inefficiently so as to increase the welfare level, and natural balance had continuously changed through advancing technology. Using the resources continuously and changing the environment with the aim of raising the welfare level had caused it to reach a level posing a risk for the future of all living creatures. However, as the natural resources are limited and the number of living creatures is constantly decreasing, resource consumption, environmental degradation and pollution have arisen (Tıraş, 2012). In this period, natural environment issues have stayed in the background for the countries that provided economic development. Ecological problems are regarded as the issues that will be addressed after economic development and industrialization processes are completed. According to this understanding, the development will be provided and solutions for the pollution arising from the development will be searched after they arise (Appleton, 2006). However, ever-increasing ecological problems have become the most important agenda of modern societies. Developing and implementing actions for problem 
solutions will be possible with the cooperation of all the countries. This, considering the future of the world, should be the primary target of all the modern societies (Akıllı, Kemahlı, Okudan, \& Polat, 2008). Ecological problems have already crossed the country borders and it has become a global problem which will influence the lives of next generations. Everincreasing ecological problems have become the most important agenda of modern societies. Sensitivity to the problems that will influence the world and lives of all the living creatures is of high importance (Aydın \& Ünaldı, 2013). In line with the common goals of the countries, people have been in the search of maintaining the natural balance since 1970s. It has led to the dilemma of: Economic development? Or maintenance and development of ecological balance? Instead of solely economic development understanding involving production and consumption, an understanding that states production takes place in a limited ecosystem and that emphasizes the importance of environmental protection should be adopted. The term of "Sustainable Development" has been coined to overcome climate and ecology problems (Dixon \& Carrie, 2016).

The term of "Sustainability" has been used in English recently. In addition, this term was defined and it became an English word in 1987. However, the word "sustain" has been used since 1250s. Traditionally, the word "sustain" was derived from "sustenance". It means "sustaining life". Furthermore, "sustentation" means the activeness of life through vital processes (Appleton, 2006).

As sustainable development is an interdisciplinary term and it is associated with each discipline, individuals have defined and interpreted this term in accordance with their priorities. The term of sustainable has been regarded as an economyprioritized field and it has been assessed by focusing on the first economic development size. When the increased ecological problems are addressed as a priority, sustainable development has become a central issue as an ecological dimension and assessed accordingly. No matter in which period, sustainability is a term that involves economic, social and ecological fields, that is in interaction with each other and that has various dimensions (Özgenç, 2015).

\section{Sustainable Development}

While definition of sustainable development is used by many stakeholders, definitions and interpretations may vary. Because structures and conditions of each country, society and individual are different. Therefore, the need for a new "Sustainable Development" definition, which is based on integration, has arisen (Summers, Corney \& Childs, 2004). Sustainability means the endurance of a thing. When considered as a term of time, it is a term which covers both present and future time. Sustainable development understanding focuses on human. (Karabıçak \& Özdemir,2015). In scientific terms, sustainability is to ensure diversity and productivity of the systems (Aliyev \& Aslanlı 2015).

Although the essentials of sustainable development dates back to $19^{\text {th }}$ century, the term first came to be known with Brundtland Report of United Nations World Commission on Environment and Development that was organized in 1987. In 1987, Sustainable Development was defined in "Brundtland Report", also known as "Our Common Future". According to this report, sustainable development is: "the development that meets the needs of the present without compromising the ability of future generations to meet their own need." (WCED, 1987). Nowadays, various definitions are made while the definition of "Sustainable Development" is difficult and its content is continuously improving (Kilinc \& Aydin, 2013).

Definitions of sustainable development included in different studies are as follows:

It is a system which stipulates that natural and cultural resources be consumed by taking the needs of next generations into consideration while fulfilling the economic and social needs of the population (Tiraş, 2012).Primary subject of sustainable development is to enhance the quality of life and to ensure the continuous protection of environment with the quality of human life while increasing the social welfare and economic growth (Aliyev \& Aslanlı, 2015). It considers the production values by maintaining the natural resources, and it is based on the utilization through the process of resources (Öztürk Demirbaş, 2015). In another definition, it is described as the use of world resources without consuming them, which redresses a balance between the current human needs and the ecosystem, and as a term which has environmental, institutional and social indicators and which enables next generations to meet their own needs (Demirci Güler, 2013). It is sustainable development when human activities are included in nature's carrying capacity in relation to a population or the natural environment in which this population lives or maintains their lives (Keleş, 2010). These various different definitions have created a need for a new definition based on global integration. 
"Sustainable Development" is the increasing production of new resources by using the available ones in an efficient and productive way so as to ensure that a system or an entity proceeds without being interrupted; the maintenance of natural balance while realizing this function; and a term which directs the system that supports the improvement and reinforcement of generational and intergenerational life standards, social solidarity and the increase of equality of opportunity.

\subsection{Dimension of Sustainable Development}

It is described in Brundtland Report that Sustainable Development has, in general terms, three dimensions. These dimensions are Economy, Ecology and Society. Although it is unlikely to distinguish these three dimensions, some counties attach importance to economic dimension considering their own production and consumption while some other counties place emphasis on environmental dimension as species are becoming extinct and they try to save these species (Alkış, 2007). According to World Commission on Economic Development, we should coordinately adopt environment, economy and social principles so as to ensure sustainable development (Sarıkaya \& Kara, 2007). Sustainable Development reaches both social, economic and environmental dimensions, and the dimensions of global responsibility and political participation (Alkış, 2007). Dimensions of sustainable development are demonstrated in Figure 1 (Benli Özdemir \& Arık, 2013).

Figure 1: Dimensions of sustainable development are demonstrated

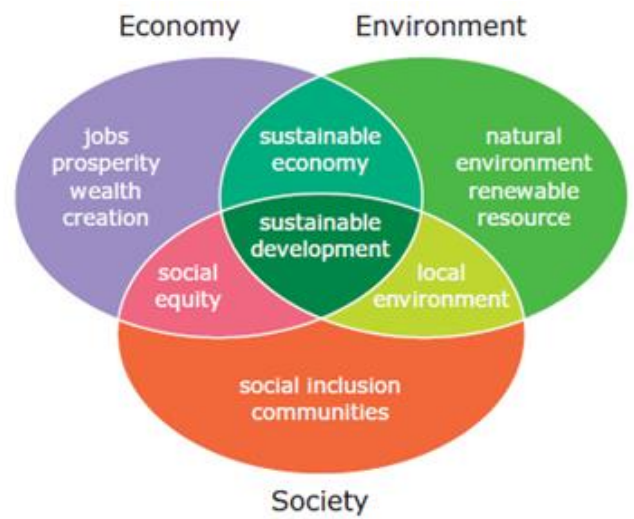

According to Figure 1, economic dimension of sustainable developments involves the use of resources. At this point, economic dimension covers the issues such as fulfillment of individuals' basic needs, financially fair share, savings, profits, economic growth and research and development. Economic sustainability covers the sustainability of the nature as well. The goal of economic development is to ensure that all individuals have employment opportunities and to improve the life standards. For some countries, it means the consumption of more natural resources while for others it means solidarity and life styles protecting the new resources (Alkış, 2007). The environment should be considered as the overall factors that have influence on the lives of living creatures. (Tiraş, 2012). Environmental dimension means effective and economical use of natural resources; prevention of air, soil and water pollution; ecological capacity; biological production and environmental management. Social dimension of sustainable development covers the issues such as cultural diversity, social sustainability, social justice, increase of participation, equality of opportunity and education. Social sustainability means equal living chance for everybody (Barbier, 1987).

\subsection{History of Sustainable Development}

The term sustainable development was coined in late 1980s. World Commission on Environment and Development supported the creation of this term. The term of sustainable development first defined in Our Common Future Report (Brundtland Report) by United Nations World Commission on Environment and Development that was organized in 1987. Before the creation of this term, environment and development trainers had concerns at two levels. First one was to support the development and the second one was to protect the environment (Kilinc \& Aydin, 2013). Before this report, Club of 
Rome 33 had prepared a report called "Secrets of Development" in 1972. According to this report, the world would reach "the limits of growth". United Nations Conference on Environment and Development was organized in Brazil, Rio De Janerio in 1992. Primary agenda topic of that conference was "Sustainable Development". In that conference, poverty took an important place and it was stated that poverty should be eradicated so as to ensure a sustainable development. Sustainable development focused on human, and it was agreed that people spend nature compatible, healthy and productive lives (UNESCO, 2010). The World Summit on Sustainable Development was organized in The Republic of South Africa, Johannesburg in 2002. In that world summit; Sustainable Development, social development and environmental protection were declared in local, national, regional and global terms, and it was decided that this term would be popularized at social development level and in terms of environmental protection (Kilinc \& Aydin, 2013). The conference involves an implementation plan and a political notification signed by heads of states and governments. Water and public health, energy, health, agriculture and biological diversity were the issues that became priority during the conference (Uçak, 2010).

The goals of the abovementioned implementation plan can be summarized as (MFA, 2002):

- To reduce the number of people who are not provided with clean and waste water services by 2015.

- To reduce the loss of biological diversity by 2015.

- To reach the highest productivity level in the field of fishery by 2015.

- To improve the access to the shelters, territories and lands as well as other issues so as to ensure that lives of minimum 100 million people who live in unfavorable conditions are improved, and, to that end, to ensure that local authorities implement programs by 2020 .

- To provide 2 billion people, who still do not have access to the energy, with energy and to increase the share of renewable energy resources.

- To reduce adverse effects of use and production of chemicals on human health and environment by 2020.

- To develop a cooperation so as to reduce air pollution at international, regional and national levels and to encourage countries to approve Kyoto Protocol.

- To support mechanisms that bring innovation in terms of addressing debt problems of countries in the development process comprehensively.

United Nations Conference on Sustainable Development (Rio+20) entitled "The future We Want" was organized in Brazil, Rio De Janerio in 2012. The previous notification was strengthened during that conference. The primary goal of the conference was to address sustainable development with economic, ecological and social dimensions, and the conference had emphasized that each country could adopt different approaches in accordance with their national conditions and priorities. Eradication of poverty, achievement of economic growth, reinforcement of social content, improvement of human welfare level and contribution to create employment opportunities for everybody and esteemed employment chances were adopted (UNCSD, 2012).

Many steps were taken for sustainable development in international arena. From the emergence of the term of sustainable development in the international arena until now, dimensions of sustainable development have changed and developed. The diagram which demonstrates the relationship between the steps of sustainable development that were taken in the international arena and its dimensions is stated below in Figure 2. 
Figure 2. TheEvolution of Dimension of Sustainable Development

\begin{tabular}{|c|c|c|c|c|c|}
\hline \multirow[t]{2}{*}{ Year } & \multirow{2}{*}{ Before 1987} & 1987 & 2002 & 2012 & \multirow[t]{2}{*}{ After 2012} \\
\hline & & $\begin{array}{l}\text { Brundtland } \\
\text { Report }\end{array}$ & $\begin{array}{l}\text { Johannesburg } \\
\text { Summit }\end{array}$ & $\begin{array}{l}\text { Rio+20 } \\
\text { Summit }\end{array}$ & \\
\hline
\end{tabular}
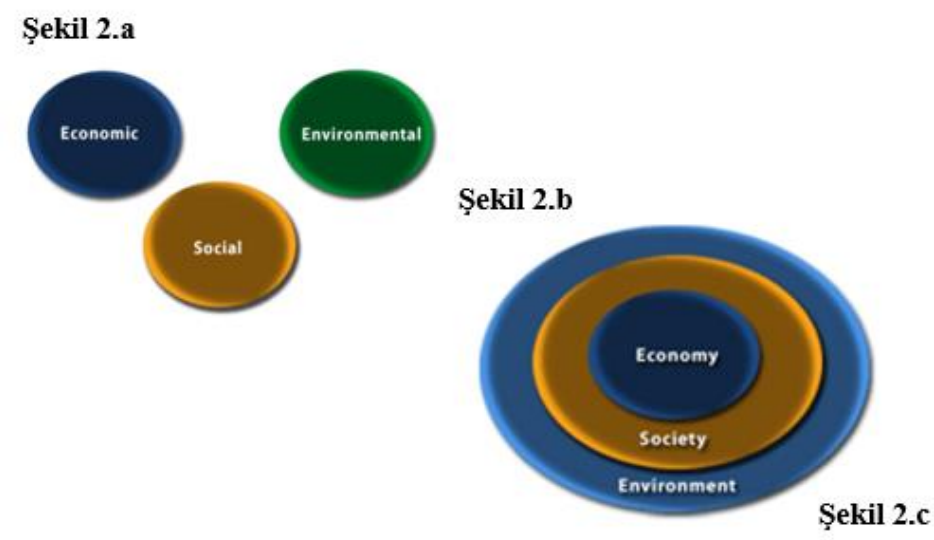

TheEvolution of Dimension of Sustainable Development

Before 1987 Brundtlant report, three dimensions of sustainable development - ecology, economy and society - were considered independent of each other (Figure 2.a). In the aftermath of Brundtland report, dimension of sustainable development were improved and categorized. First of them is also known as "Russian Doll" diagram (Figure 2.b). According to this diagram, even though economic dimension seems to be at the center, it is actually dependent on the society and the environment. The environment covers the dimensions of economy and society, and it can continue its existence independently, without economy and society. The diagram demonstrating the coordination of dimensions of sustainable development is the most sought-after (Figure 2.c). In this model, it is stated that sustainable development can be ensured with coordinated implementation of its three dimensions. It is also known as the most-adopted model (Wu, Liou, \& Su, 2014)

\section{Sustainable Development in Science Education}

In $21^{\text {st }}$ century, people encounter social, economic and environmental problems. A livable world cannot be ensured only with measures taken in the field of technology, law, policy and economy. People should change their life styles for a sustainable life, too. These changes can only be ensured through education (Allen, Emery, Nailon, Dyment, Getenet, 
McCrea \& Davis, 2014). For Sustainable Development, education should start at preschool level and should continue for a lifetime. It should have a quality to transform the education provided to the individuals into a behavior. Awareness, approaches and values of individuals that can be transformed into behavior for a sustainable life and world can be turned into a life style (Öztürk Demirbaş, 2015). Even though education alone is not adequate, it is a primary obligation in achieving a sustainable universe. It is expected that people take actions for a more sustainable world in a system that is created with the contributions of educators from all over the world (UNESCO, 2010).

Education given to individuals is a must for people to absorb the achievements regarding their concerns on sustainable development. It has been stated that education is a must for changing life styles and value judgments that can meet the sustainable development needs of individuals who will be a model and guide for next generations, and that it is possible to realize this change in the educational institutions (Keleş, Uzun and Özsoy, 2008; Burmeister \& Eilks, 2013). In this sense, it is not possible that science education is not included in the education of tomorrow's citizens for the future of the world. Science education is based on the creation of information society, industrial production and technological developments. Science plays a key role in protection of human life, economic development and natural balance, in other words sustainable development. Therefore, science education and sustainable development are complementary elements (Birdsall, 2013).

A significant science education has the quality to guide us in philosophical thinking, logical and model thinking, behavior and actions. Students' problem solving, decision-making, questioning, critical thinking, development of high cognitive skills are important elements of sustainable development, and they are directly connected to the science. People who face various complicated problems in the world encounter decision-making mechanisms to solve these problems. They may not respond to these duties excluding cognitive ones (Zoller, 2012). Science education may help individuals in giving the right decision in such socio-scientific issues as reduction in the biological diversity, consumption of energy resources, recycling and clean environment. Although science education helps individuals make decisions on sustainable development, sustainability is still a difficult term. Even though science education is an auxiliary element in realizing sustainable development, it remains insufficient. In addition to science education, economic and financial structuring is required. Considering sustainability for science education, we see that socio-scientific issues such as biological diversity, energy resources, recycling and clean environment dominate. As well as being interrelated, these issues are related to the dimensions of economy, culture and policy (Bögeholz \& Barkmann, 2014). Individuals' attitude and behaviors in these issues can only be changed through science education that is provided in a qualified way (Eilks \& Hofstein, 2014).As an efficient education system provided in line with the goals of Sustainable Development ensures individual and collective responsibility and provides behavioral changes, it has an important role in understanding and interpreting sustainable development (Tanrıverdi, 2009; Mills and Tomas, 2013). Education given to individuals is a must for people to absorb the achievements regarding their concerns on sustainable development. It has been stated that education is a must for changing life styles and value judgements that can meet the sustainable development needs of individuals who will be a model and guide for next generations, and that it is possible to realize this change in the educational institutions (Keleş, Uzun ve Özsoy, 2008; Burmeister \& Eilks, 2013). In this sense, it is not possible that science education is not included in the education of tomorrow's citizens for the future of the world. Science education is based on the creation of information society, industrial production and technological developments. Science education plays a key role in protection of human life, economic development and natural balance, in other words sustainable development. Therefore, science education and sustainable development are complementary elements (Birdsall, 2013). The term sustainable development lies behind how students should take responsibility for the society they live in now and in the future. The question here is: "How do people from every walk of life or individuals receiving education at school absorb the understanding of sustainable development?" The answer is hidden in an education program servings as a model for sustainable development within the scope of science education (Mogensena, F., \& Schnack, K, 2010). Biological diversity, energy resources, recycling and clean environment - the primary subjects of sustainable development - are included in the subjects of this model program. The education to be provided to the individuals should be in line with constructivist approach, which enables students to absorb sustainable development and to transform it into a behavior. The individuals absorbing sustainable development have more qualified cognitive, emotional and psychomotor skills and they transform these skills into a behavior in their normal lives. When all the individuals absorb sustainable development, the world will reach a more livable and sustainable level (Armstrong, 2011). 


\section{Discussion and Conclusions}

Negative effects of people on the nature are increasing day by day. There are three negative and critical factors which people have on the nature. These factors are industrialization, urbanization and rapid population growth. Especially growth of human population and thereby fast consumption and production has posed a threat for the future of the world (Chivu, 2015). However, people still assume that natural and available resources are limitless (Ruff \& Olson, 2009). Counties gave priority to economic development and completed their industrialization especially during and after Second World War. In that period, world production had increased in early 1900s. Therefore, some counties become rich very quickly. As a result, use of natural resources had exceeded the replacement capacity, and serious problems such as forest destruction, reduction in the biological diversity and climate change had arisen (Appleton, 2006). In that period, priority was given to the economic development such as fast development, prevention of unemployment and control of inflation, and creation of environmental consciousness was delayed (Lupan, \& Cozorici, 2015). Ecological problems have already crossed the country borders and it has become a global problem which will influence the lives of next generations. Ever-increasing ecological problems have become the most important agenda of modern societies. Thus, the term of "Sustainable Development" has been coined to overcome ecological problems. According to understanding of sustainable development; economic, social and environmental development should be advanced coordinately. However, economic development and growth was aimed in the traditional understanding and social and environmental dimensions were ignored. However, it caused overconsumption of resources, the widened gap between the rich and the poor, pollution of available resources, meaningless competition and tension between people and gaining momentum in the global warming (Aliyev \& Aslanlı 2015). Researches have showed that more and more biologically productive fields are used as the development level of the counties increases. Overconsumption has risen with the enrichment of the countries and increase of their income level. Depending on the consumption; more energy was used, much more environmental pollution occurred and natural balance was upset (Akıllı, Kemahlı, Okudan \& Polat, 2008). The below graphic (Figure 3) shows the biological capacity of the world and ecological footprints of individuals per capita, in other words the environmental damages (GFN, 2012).

Figure 3: Biological capacity of the world and ecological footprints of individuals per capita.

\section{World}

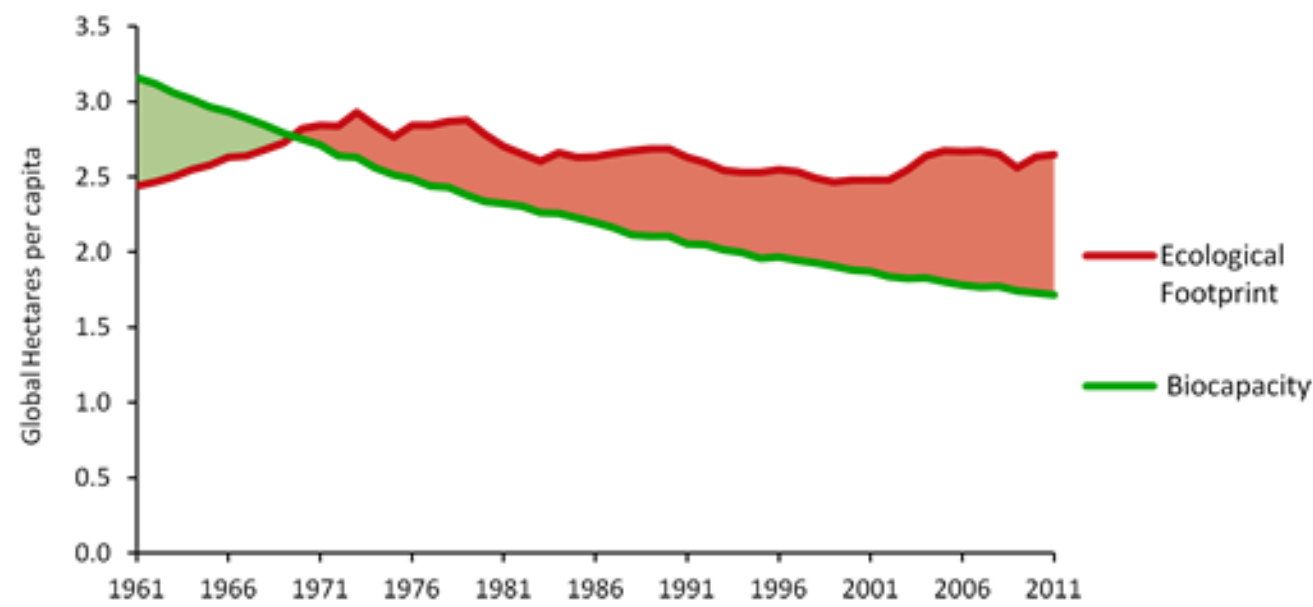

As understood from the graphic, people have exceeded the biological carrying capacity of the world. This poses a risk for the future of the universe. Counties should adopt the sustainable development understanding so as to make the world a more livable place. There are two aspects of sustainable development: strong and weak sustainability. According to strong sustainability, world resources can be protected with the use of renewable resources only and, thereby, resources can be 
transferred to the next generations. In other words, non-renewable energy resources will lead to the decrease in the number of natural resources and they will disappear quickly. Weak sustainability argues that use of natural resources by the present generation is a right and that the capital to emerge as a result of its use will offer different alternatives (Kılıç, 2012). Developed counties have completed their industrialization, and thereby the environment has been polluted and its solution has been sought in "sustainable development". In addition to this, an environmental conference was organized with the participation of various countries under the leadership of developed counties and under the roof of United Nations, and certain decision were made. However, sustainable development understanding can be considered as an obstacle for less developed or developing counties in terms of their own development. Because basic needs of individuals in the countries having low national income should be met and their economic welfare level should be improved in order to carry their lives to a livable level. Industrial production and modernization of agriculture will be a prerequisite for development and modernization. While doing it, the waste will be a problem. When considering development and environmental pollution together, we will see that there is a paradox (Tıraş, 2012).

It may not be correct to say that low-income individuals are environmentally less conscious. The reason is that food and shelter, which are the basic needs of low-income individuals, are more prioritized than environmental pollution. As the development levels of the counties increase, productivity of the firms and personal income will increase, too. When the basic needs are met, individuals will become more sensitive to different fields. People will tend to demand products that will harm the environment less. However, less demand for products that will harm the environment more and more demand for environment friendly products will decrease the pollutants and environment friendly companies will carry on their production (Alagöz, 2007). Eradication of poverty is the biggest global challenge and it is an indispensable requirement of sustainable development UNCSD, 2012). An industrial structure walking hand in hand with the natural environment is a must for all developed and developing counties. While developing economically, it should be an obligation that we raise awareness on the environmental risks for the world and next generations (Karabıçak \& Özdemir 2015). Efficient use of international investment and financial mechanisms in the transfer and dissemination of new environment friendly technologies in developing counties is important (Aliyev \& Aslanlı 2015). Another principle of sustainable development includes a common but differential responsibility principle. Thus, it imposes various obligations for all participants. In this sense, sustainable development may result in taking unintended decisions. Sustainable development has a democratic structure, too. If sustainable development does not have a democratic structure, it will be dogmatic and moralistic (Mogensena \& Schnack, 2010).

\section{REFERENCES}

[1] Alagöz, M. (2007). Sustainable development in the environmental factor: A theoretical overview. International Refereed Online Journal of Social Science, 11, 1-12.

[2] Aliyev, E., \& Aslanlı, K. (2015). Sustainable development performances of Muslim countries: Concepts, theories and measurements. Eurasian Studies, 47, 37-70.

[3] Alkış, S. (2007). The rising paradigm in teaching geography: A sustainable World. Marmara Geographical Review, 15, 55-64.

[4] Akıllı, H., Kemahlı, F., Okudan, K., \& Polat, F. (2008). The content of ecological footprint concept and calculation of individual ecological footprint in the Akdeniz Universty Economics and Administrative Sciences Faculty. Akdeniz Universty Journal of Faculty of Economics and Administrative Sciences, 15, 1-25.

[5] Allen, H.,Emery, S., Nailon, D., Dyment, J., Getenet, S., McCrea, N., \& Davis, J.M. (2014). Exploring how adultswhoworkwithyoungchildrenconceptualisesustainabilityanddescribetheirpracticeinitiatives. AustralasianJournal of EarlyChildhood. 39(3), 14-22.

[6] Armstrong, C. M. (2011). Implementing education for sustainable development: The potential use of timehonored pedagogical practice from the progressive era of education. Journal of Sustainability Education, 2. Retrieved from: http://www.jsedimensions.org/wordpress/wp-content/uploads/2011/03/Armstrong2011.pdf

[7] Appleton, A.F. (2006). Sustainability: A practitioner's reflection. Technology in Society, 28, 3-18. 
[8] Aydın, F., \& Ünaldı, Ü.E. (2013). Geography teacher candidates' attitudes towards sustainable environment. Kalem International Journal Of Education And Human Sciences, 3 (1), 11-42.

[9] Barbier, E. B. (1987). The concept of sustainable economic development. Environmental Conservation, 14(2), 101-110.

[10] Benli Özdemir, E., \& Arık, S. (2013) The investigation self-esteem levels and attitudes towards a sustainable environment of the secondary school students. Journal of History School (JOHS), 6(16), 641-655.

[11] Birdsall, S. (2013). Reconstructing the relationship between science and education for sustainability: A proposed framework of learning. International Journal of Environmental \& Science Education, 8, 451-478.

[12] Bögeholz, S., \& Barkmann, J. (2014). "...to help make decisions": A challenges to science education research in the $21^{\text {st }}$ century. Science Education Research and Education for Sustainable Development. A Collection of Invented Papers Inspired by the $22^{\text {nd }}$ Symposium on Chemistry and Science Education Held at the University of Bremen, 3-14, Germany.

[13] Burmeister, M., \& Eilks, I. (2013). An Understanding of Sustainability and Education for Sustainable Development among German Student Teachers and Trainee Teachers of Chemistry. Science Education International, 24(2), 167-194.

[14] Chivu, R. M. (2015). Sustainable development, a solution to the ecological crisis. Hyperion International Journal of Econophysics \& New Economy. 8(1), 227-232.

[15] Demirci Güler, M. P. (2013). The behavior levels of academic staff towards sustainable environmental education. International Journal of Eurasia Social Sciences, 4(13), 67-82.

[16] Dixon, A., \& Carrie, R. (2016). Creating local institutional arrangements for sustainable wetland socio-ecological systems: Lessons from the 'Striking a Balance' project in Malawi. International Journal of Sustainable Development \& World Ecology, 23(1), 40-52.

[17] Eilks, I., \& Hofstein, A. (2014). Combining the question of the relevance of science education with the idea of education for sustainable development. Science Education Research and Education for Sustainable Development. A Collection of Invented Papers Inspired by the $22^{\text {nd }}$ Symposium on Chemistry and Science Education Held at the University of Bremen, 3-14, Germany.

[18] Karabıçak, M., \& Özdemir, M. B. (2015). Conceptual basis of sustainable development. Suleyman Demirel University Th eJournal of Visionary, 6(13), 44-49.

[19] Keleş, Ö. (2010). The indicator of the sustainable life: The ecological footprint. Nature and Men. 3-10.

[20] Keleş, Ö., Uzun, N., \& Özsoy, S. (2008). Measuring and evaluating pre-service teachers'

[21] ecological footprints. Aegean Journal of Education, 9(2), 1-14.

[22] Kilinc, A., \& Aydin, A. (2013). Turkish student science teachers' conceptions of sustainable development: A phenomenography. International Journal of Science Education, 35(5), 731-752.

[23] Lupan, M., \& Cozorici, A.N. (2015). Sustainable economic growth and eco-efficiency. The USV Annals of Economics and Public Administration, 15(1), 63-73.

[24] MFA, http://www.mfa.gov.tr/dunya-surdurulebilir-kalkinma-zirvesi_johannesburg_-26-agustos---4-eylul2002_tr.mfa). (Accessed: 03.01.2016)

[25] Mills R., \& Tomas, L. (2013). Integrating education for sustainability in pre service teacher education: A case study from a regional Australian University. Australian Journal of Environmental Education 29(02)152-164.

[26] Mogensena, F., \& Schnack, K. (2010). The action competence approach and the 'new' discourses of education for sustainable development, competence and quality criteria. Environmental Education Research, 16(1), 5974. 
[27] GDN (2012). Global Footprint Network, The National Footprint Accounts, 2012 edition. http://www.footprintnetwork.org/images/article_uploads/National_Footprint_Accounts_2012_Edition_Report.pd f (Accessed: 03.05.2016).

[28] Öztürk Demirbaş, Ç. (2015). Sustainable development awareness levels of teachers pre-service. Marmara Geographical Review, 31, 300-316.

[29] Özgenç, N. (2015). Reunderstanding poverty notion under the concept of sustainability: Poverty knot. Journal of Social Policy Studies, 35, 101-136.

[30] Summers, M., Corney, G. \&Childs, A. (2004). Student teachers' conceptions of sustainable development: The starting points of geographers and scientists. Educational Research,46(2), 63-182.

[31] Ruff, C. L., \& Olson M.A. (2009). The attitudes of interior design students towards sustainability. International Journal of Technology and Design Education, 19(1), 67-77.

[32] Sarıkaya, M., \& Kara, F. Z., (2007), The role of business for sustainable development: Corporate citizenship. Journal of Management and Economics Celal Bayar University The Faculty of Economic and Administrative Sciences Journal, 14 (2), 221-233.

[33] Sewilam, H., McCormack, O., Mader, M., \& Raouf, M.A. (2015). Introducing education for sustainable development into Egyptian schools. Environ Dev Sustain, 17:221-238.

[34] Tanrıverdi, B. (2009). Analyzing Primary School Curriculum in Terms of Sustainable Environmental Education. Education and Science, 34(151), 89-103.

[35] Tıraş, H.H. (2012). Sustainable development and environment: An examine in theory. Kahramanmaraş Süţü Imam Universty Journal of Faculty of Economics and Administrative Sciences, 2(2), 57-73.

[36] Uçak, S. (2010). Alternative energy in the regard of sustainable development and energy production growth relationship: Panel-data analysis. Unpublished Doctoral Dissertation, The Enstitude of Social Sciences, University of Kocaeli, Kocaeli.

[37] UNCSD. (20112). United Nations Conference on Sustainable Development (Rio+20). "The Futur We Want" Outcome of the Conference. http://www.cem.gov.tr/erozyon/Files/Rio20SonucBildirgesii.pdf (Accessed: 04.01.2016

[38] United Nations Educational, Scientific and Cultural Organization [UNESCO]. (2010). Education for Sustainable Development. Available at: http://www.unesco.org/en/esd/ (Accessed: 13.01.2016).

[39] WCED. (1987). World commission on environment and development, our common future. Oxford: OUP. http://www.undocuments.net/wced-ocf.htm (Accessed: 05.02.2016).

[40] Wu, P.I., Liou, J.L., \& Su, M.T (2014). Examination of the diverse views of sustainable development: An approach to monetize the environment, economy, and society. Environmental Economics, 5(1), 62-75.

[41] Zoller, U. (2012). Science education for global sustainability: What is necessary for teaching, learning, and assessment strategies? Journal of Chemical Education. 89, 297 - 300. 